\title{
FEATURES OF THE USE OF PROTEIN \\ PREPARATIONS IN THE STRUCTURE \\ OF RESTRUCTURED HAM PRODUCTS
}

\author{
V. Zhuk, I. Shevchenko, O. Topchii \\ National University of Food Technologies
}

Y. Kryzhova

National University of Life and Environmental Sciences of Ukraine

\begin{tabular}{l} 
Key words: \\
Protein \\
Fat \\
Emulsion \\
Stability \\
Ingredients \\
Mixtures \\
\hline
\end{tabular}

Article history:

Received 16.05.2018

Received in revised form

05.06 .2018

Accepted 19.06.2018

Corresponding author:

O. Topchii

E-mail:

oksanatopchiy@ukr.net
ABSTRACT

The urgency of the use of animal proteins is due to the considerable advantages of combining meat raw materials with them, which allows to balance the protein component of meat products and increase their biological value, bringing them closer to the needs of the organism. Simulation of the properties of raw materials with low functional and technological characteristics is possible due to the introduction of protein-fat emulsions (PFE) into its composition, which stabilize the structure of meat systems and supply the action of meat proteins in the composition of products.

The article substantiates the possibility of using PFE in the recipe of restructured ham products in order to stabilize functional and technological properties of meat systems and increase their nutritional and biological value by balancing the amino acid and fatty acid composition. Model specimens of PFE were developed using milk proteins - sodium caseinate DairiCo and buttermilk, Vepro 75 PSC blood plasma protein, turkey skin, pork and turkey fats and water. The technological functions of the selected protein ingredients were investigated and their positive influence on qualitative indices of restructured ham products was established. It is proved that the best functional and technological properties are PFE, which includes a mixture of animal proteins in the ratio: 1\% of proteins of blood plasma Vepro 75 PSC and $1 \%$ mixture of milk proteins $(70 \%$ caseinat sodium and oil 30\%). On the basis of the principle of balancing fatty-acid composition, the ratio of turkey fats and pork fats was computed as a part of PFE (67\% of turkey fats and 33\% of pork fats) and their rational quantity was established. The developed composition of PFE positively affects the formation of qualitative indicators of restructured ham products and promotes the improvement of functional properties of meat raw materials with low technological characteristics.

DOI: $10.24263 / 2225-2924-2018-24-3-23$ 


\title{
ОСОБЛИВОСТІ ВИКОРИСТАННЯ БІЛКОВИХ ПРЕПАРАТІВ У СКЛАДІ РЕСТРУКТУРОВАНИХ ШИНКОВИХ ВИРОБІВ
}

\author{
В.О. Жук, І.І. Шевченко, О.А. Топчій \\ Національний університет харчових технологій \\ Ю.П. Крижова \\ Національний університет біоресурсів і природокористування Украӥни
}

Актуальність використання тваринних білків зумовлена перевагами комбінування з ними м'ясної сировини, що дає змогу збалансувати білкову складову м'ясних продуктів і підвищити їхню біологічну цінність, наблизивши до потреб організму. Моделювання властивостей сировини з низькими функиіонально-технологічними характеристиками є можливим за рахунок введення до їі складу білково-жирових емульсій (БЖЕ), що стабілізують структуру м'ясних систем і доповнюють дію м'ясних білків у складі виробів.

У статті обгрунтовано можливість використання БЖЕ у рецептурі реструктурованих шинкових виробів з метою стабілізації функиіональнотехнологічних властивостей м'ясних систем і підвищення їхньої харчової та біологічної цінності шляхом збалансування амінокислотного й жирнокислотного складу. Модельні зразки БЖЕ були розроблені з використанням молочних білків - казеїнату натрію «DаiriCо» та маслянки, білка плазми крові Vepro 75 PSC, індичої шкурки, свинячого та індичого жирів і води. Досліджено технологічні функиї обраних білкових інгредієнтів і встановлено їхній позитивний вплив на якісні показники реструктурованих шинкових виробів. Доведено, що найкрашими функціонально-технологічними властивостяли володіє БЖЕ, до складу якої входить суміш тваринних білків у співвідноменні 1\% білків плазми крові Vерго 75 PSC та 1\% суміш молочних білків (казеїнат натрію - 70\%, маслянка - 30\%). За принципом збалансування жирнокислотного складу розраховано співвідночення індичого й свинячого жирів у складі БЖЕ (67\% індичого та 33\% свинячого) і встановлено їх рачіональну кількість.

Розроблений склад БЖЕ позитивно впливає на формування якісних показників реструктурованих шинкових виробів $i$ сприяє підвищенню функиіональних властивостей м'ясної сировини з низькими технологічними характеристиками.

Ключові слова: білок, жир, емульсія, стабільність, інгредієнти, суміші.

Постановка проблеми. Сучасні принципи розробки рецептури м'ясних виробів грунтуються на виборі певних видів сировини і такого ї співвідношення, яке б забезпечувало досягнення потрібної (прогнозованої) якості готових продуктів, включаючи кількісний вміст і якісний склад харчових речовин, наявність певних органолептичних показників, споживчих і технологічних характеристик. При цьому одночасно вибрані компоненти рецептури повинні відповідати другій, не менш важливій, вимозі: мати прийнятні функціонально-технологічні властивості, максимальну їх сумісність або взаємокомпенсацію, що забезпечує в процесі перероблення сировини отримання стабільних м'ясних систем. 
Аналіз останніх досліджень і публікацій. Останнім часом поступово зростає інтерес виробників м'ясної продукції до застосування білків тваринного походження, що виділяються 3 м'ясної та молочної сировини. Це білкові препарати, які виробляються на основі плазми крові, та білки, які виробляються з колагеновмісної сировини і містять колаген, еластин, а також молочні білки, що отримують 3 вторинних продуктів переробки молока: казеїнати, білки сироватки та маслянки [1-3]. Молочні білкові компоненти природно поєднуються 3 м'ясною сировиною, є хорошими емульгаторами, стабілізаторами структури та за своїми функціонально-технологічними властивостями наближаються до м'язових білків. Сучасні технології отримання казеїнатів методом екструзії дають змогу покращити їх функціональнотехнологічні властивості. Завдяки майже повній відсутності лактози, кальцію та високим функціональним властивостям казеїнат натрію можна використовувати також як емульгатор при виробництві м'ясопродуктів.

У м'ясних емульсіях при формуванні мембран навколо часток жиру молекула казеїну доповнює дію солерозчинних міофібрилярних білків, стабілізуючих глобули жиру в процесі подрібнення. Дуже важливим $\epsilon$ те, що, будучи сильним емульгатором, казеїн здатний утворювати мембрану на поверхні жирових глобул без участі міозину. Стабілізація глобул жиру в емульсійних м'ясних системах при внесенні казеїнату натрію, найімовірніше, досягається за рахунок як незалежної, так і сумісної дії молочних і м'ясних білків.

Маслянка - це плазма молочних вершків, яку отримують під час перероблення їх на масло. Маслянка $є$ джерелом високоцінного білка, який містить такі амінокислоти з ліпотропними властивостями, як метіонін, цистин тощо, але в менших кількостях.

Аналіз результатів попередньо проведених досліджень підтвердив, що найкращими функціонально-технологічними властивостями володіє суміш молочних білків у такому співвідношенні: казеїнат натрію 70\% та маслянка 30\% [4]. Високі функціонально-технологічні властивості запропонованої композиції молочних білків обумовлені також наявністю в складі маслянки значної кількості фосфоліпідів, що володіють високою емульгуючою здатністю. На молекулярному рівні молочні білки зв'язують воду за рахунок утворення водневих зв'язків у середині гідратованого білка, що сприяє підвищенню щільності продукту.

Водорозчинні білки, такі як плазма крові, завдяки наявності в них фібриногену, є повноцінними, і відрізняються від гемоглобіну білыш високим вмістом таких незамінних амінокислот, як триптофан, метіонін, і вмістом ізолейцину, який відсутній у складі гемоглобіну [1-3].

Білковий препарат плазми крові Vepro 75 PSC за функціонально-технологічними властивостями не поступається сполучнотканинним білкам. Так, альбуміни легко взаємодіють з іншими білками, можуть бути зв'язані з ліпідами і вуглеводами, мають високу водозв'язуючу і піноутворюючу здатність. Глобуліни - хороші емульгатори. Фібриноген має виражену гелеутворюючу здатність: він переходить у фібрин під впливом ряду факторів (зсув $\mathrm{pH}$ до ізоелектричної точки, введення іонів $\mathrm{Ca}^{+}$в плазму) й утворює просторовий каркас. Усі білки плазми характеризуються доброю розчинністю, i, як наслідок, високою водозв'язуючою та емульгуючою здатністю: при нагріванні 
вони утворюють гелі, причому міцність гелів і їх водозв’язуюча здатність залежать від концентрації білків у системі, величини рН, наявності солей, температури і тривалості нагрівання [4-6].

Користь свинячого жиру полягає в тому, що він містить особливо важливі для організму людини вітаміни, зокрема провітамін А, лінолеву кислоту та набагато більшу кількість незамінних жирних кислот, ніж у значній частині інших твердих жирів, невисокий вміст холестерину.

Жир індичий — відмінний продукт. Він легко засвоюється, плавиться при низькій температурі, має приємний запах ті смак. Порівняно з іншими видами тваринних жирів, індичий жир містить рекордну кількість вітамінів групи Е, а також D. Проте при внесенні жирів безпосередньо у фаршеву емульсію не в складі БЖЕ, вони обумовлюють появу в готовому продукті таких дефектів консистенції, як мазеподібність, липкість [7].

Найбільш раціональним шляхом використання додаткових джерел тваринного білка та жировмісної сировини в складі м'ясних виробів $є$ впровадження у виробництво білково-жирових емульсій (БЖЕ). Використання БЖЕ дає змогу не тільки комбінувати рецептурний склад реструктурованих шинкових виробів на основі ефекту взаємного збагачення, але й сприяє підвищенню їх соковитості та ніжності за рахунок внесення жиру. Крім того, в складі БЖЕ жир краще засвоюється організмом людини.

П.А. Ребіндером встановлено, що найбільш важливим для збереження стабільності одержуваних емульсій, особливо концентрованих, є так званий структурно-механічний бар'єр, коли міжфазна сорбційна оболонка структурується і ії структурна в'язкість при малих градієнтах швидкості у багато разів перевищує в'язкість дисперсійного середовища. Відомо, що розчин кухонної солі викликає швидке розшарування емульсії й укрупнення жирових кульок при контакті з розсолом. Проте у харчовій промисловості вибір емульгаторів обмежений, тому до них, крім володіння здатністю знижувати поверхневу енергію, висуваються вимоги 3 точки зору споживчих властивостей.

Мета дослідження: використовуючи можливості математичного моделювання, спрогнозувати склад і вивчити властивості БЖЕ відповідно до технологічних потреб та існуючих медико-біологічних вимог.

Матеріали і методи. Матеріали дослідження — рецептурні композиції для виготовлення білково-жирових емульсій 3 суміші білків плазми крові Vepro 75 PSC, казеїнату натрію, маслянки та індичого і свинячого жирів.

Методи досліджень - органолептичні, хімічні, фізико-хімічні, загальноприйняті та спеціальні, виконані з використанням сучасних приладів і інформаційних технологій.

Розробку раціонального складу емульсії здійснювали методом комп'ютерної оптимізації на основі хімічного складу інгредієнтів, що рекомендуються до складу БЖЕ. Як функцію цілі було обрано жироутримуючу здатність, яка $\epsilon$ критерієм стабільності утримання жиру в м'ясних емульсіях.

Жирнокислотний склад визначали згідно з ДСТУ ISO 5509-2002 “Жири та олії тваринні і рослинні». Визначення жирних кислот здійснювали на газовому хроматографі виробництва Hewlett-Packard HР6890 із полум'яно- 
іонізаційним детектором, інжектор $\mathrm{S} / \mathrm{S}$ з виділенням потоків, колонка $\mathrm{Sp} 2380$, довжина 100 м, внутрішній діаметр 0,25 мм, товщина покриття 0,2 мкм.

Результати і обговорення. При вирішенні питань, пов'язаних зі створенням науково-обгрунтованих підходів до удосконалення існуючих технологій шинкових виробів в оболонці з використанням БЖЕ та з метою моделювання їх складу, в т. ч. відповідно до існуючих медико-біологічних вимог, було знайдено оптимальне співвідношення свинячого та індичого жирів - 33:67.

Дослідження жирнокислотного складу ліпідів та оцінка їх збалансованості показали, що переважаючими жирними кислотами в суміші з насичених жирних кислот $є$ пальмітинова і стеаринова, 3 мононенасичених - олеїнова, а 3 поліненасичених - лінолева. Проте цінність жирового компоненту характеризується не тільки абсолютним вмістом окремих кислот, але і їхнім співвідношенням. Так, співвідношення суми ненасичених і насичених кислот у ліпідах суміші свинячого й індичого жирів становить 66,42:28,99 проти рекомендованого 70:30 [8].

Жирнокислотний склад суміші жирів повністю задовольняє добову потребу за кількістю $\omega-6$ та частково за кількістю $\omega-3$. Встановлено, що розрахована жирова суміш 3 індичим і свинячим жиром має фізіологічно сприятливу для організму людини температуру застигання.

Зниження температури плавлення жирової суміші, порівняно з температурою плавлення свинячого жиру, за рахунок індичого буде сприяти збільшенню ступеня доступності впливу ферментів шлунково-кишкового тракту i підвищенню швидкості ії засвоєння.

У наш час існують різні рецептури і способи приготування білково-жирових емульсій. Проте їх застосування обмежене через складну технологію приготування і введення в сировину, а також малою стійкістю БЖЕ в процесі зберігання і при взаємодії з розсолом.

Сутність холодного способу приготування розробленої емульсії (рис. 1) полягає втому, що в кутер додають воду і казеїнат натрію, маслянку, плазму крові та гідратують протягом 5 хвилин. Жирову сировину кутерують окремо $3-5$ хв, після чого також додають у кутер.

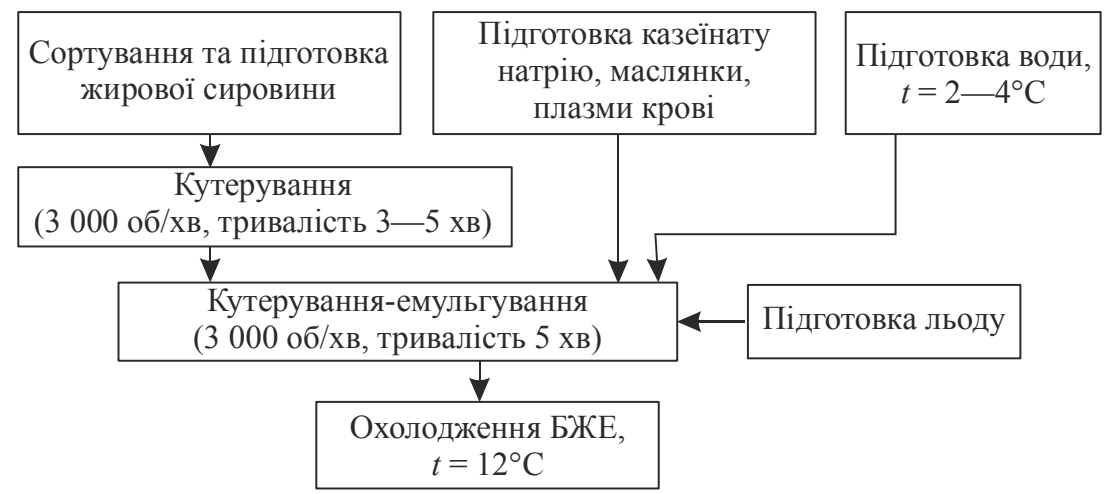

Рис. 1. Технологічна схема приготування емульсії холодним способом

Якщо за рецептурою БЖЕ передбачено використання свинячої вареної шкурки або індичої шкурки, ії вносять на заключному етапі і кутерують ще 
5-6 хвилин. Максимальна температура готової емульсії не повинна перевищувати $15-18^{\circ} \mathrm{C}$. Для зниження температури частину води вносять у вигляді льоду з метою отримання стабільної емульсії. В готову емульсію можна внести сіль і нітрит натрію. Процес завершується розливанням емульсії у ємкості товщиною шару $10 \mathrm{~cm} 3$ подальшим зберіганням в умовах низьких температур від 0 до $3^{\circ} \mathrm{C}$. Рецептурний склад розроблених білковожирових емульсій з сумішшю молочних білків представлено в табл. 1.

Жири, що використовуються для виготовлення БЖЕ, не повинні бути прогірклими, їх бактеріальне обсіменіння повинно бути мінімальним. Зазвичай, ці жири не підлягають ретельному обробленню або охолодженню, тому вміст бактерій у них достатньо високий. Але, незважаючи на їх невисоку цінність, в мікробіологічному відношенні ї необхідно обробляти як високоякісну сировину. Оптимально допустимою є загальна кількість бактерій $10^{2}-10^{4} \mathrm{KУO} / г$ продукту [7].

Таблиия 1. Рецептурний склад розроблених білково-жирових емульсій з сумішшю молочних білків

\begin{tabular}{|c|c|c|c|c|c|}
\hline \multirow{2}{*}{\begin{tabular}{c} 
Найменування компонентів \\
\cline { 2 - 6 }
\end{tabular}} & $\begin{array}{c}\text { БЖЕ 1 } \\
\text { (контроль) }\end{array}$ & БЖЕ 2 & БЖЕ 3 & БЖЕ 4 & БЖЕ 5 \\
\hline Жир свинячий & 43 & - & & & \\
\hline $\begin{array}{c}\text { Жирова суміш: жир свинячий 33\% } \\
\text { + жир індичий 67\% }\end{array}$ & - & 44 & 44 & 44 & 44 \\
\hline Вода питна & 43 & 44 & 44 & 44 & 44 \\
\hline Шкурка свиняча варена & 14 & - & - & - & \\
\hline $\begin{array}{c}\text { Суміш білків: плазма крові Vерro 75 } \\
\text { РSС 1\%, казеїнат натрію 1\% }\end{array}$ & - & & 2 & - & \\
\hline $\begin{array}{c}\text { Суміш білків (плазма крові Vерro 75 } \\
\text { РSС 1\%, молочні білки 1\% казеїнат } \\
\text { натрію70\%, сироватка 30\%) }\end{array}$ & - & - & & 2 & \\
\hline $\begin{array}{c}\text { Суміш білків (плазма крові Vерrо 75 } \\
\text { РSС 1\%, молочні білки 1\% (казеїнат } \\
\text { натрію 70\%, маслянка 30\%) }\end{array}$ & - & & 10 & & 2 \\
\hline $\begin{array}{c}\text { Стабілізатор білковий } \\
\text { з індичої шкурки }\end{array}$ & - & 12 & 10 & 10 & 10 \\
\hline Всього & 100 & 100 & 100 & 100 & 100 \\
\hline
\end{tabular}

При підборі рецептурних компонентів білково-жирової емульсії важливо враховувати їхні технологічні функції та вплив на якість готового продукту (табл. 2).

\section{Таблиия 2. Функціонально-технологічні показники БЖЕ}

\begin{tabular}{|c|c|c|c|}
\hline $\begin{array}{c}\text { Рецептури } \\
\text { емульсій }\end{array}$ & $\begin{array}{c}\text { Вологоутримувальна } \\
\text { здатність, \% (ВУ3) }\end{array}$ & $\begin{array}{c}\text { Жироутримувальна } \\
\text { здатність, \% (ЖУ3) }\end{array}$ & $\begin{array}{c}\text { Стабільність } \\
\text { емульсії, \% (СЕ) }\end{array}$ \\
\hline БЖЕ 1 (контроль) & $49,0 \pm 2,1$ & $59,8 \pm 2,5$ & $47,5 \pm 1,9$ \\
\hline БЖЕ 2 & $49,4 \pm 2,2$ & $61,4 \pm 2,8$ & $47,7 \pm 2,0$ \\
\hline БЖЕ 3 & $50,6 \pm 2,4$ & $62,9 \pm 2,7$ & $52,4 \pm 2,4$ \\
\hline БЖЕ 4 & $65,8 \pm 2,6$ & $62,5 \pm 2,2$ & $62,7 \pm 2,7$ \\
\hline БЖЕ 5 & $65,9 \pm 2,3$ & $62,6 \pm 2,2$ & $62,4 \pm 2,9$ \\
\hline
\end{tabular}


Аналіз результатів досліджень свідчить про кращі функціонально-технологічні показники БЖЕ, виготовлених з використанням суміші білків: плазма крові Vepro 75 PSC - 1\%, молочні білки - $1 \%$ (казеїнат натрію - 70\%, маслянка - 30\%). Це можна пояснити тим, що при введенні в плазму крові неплазмових білків (казеїнату натрію, маслянки) суттєво збільшується як міцність гелів, так і їх водо- та жиропоглинаюча здатність після термооброблення.

Враховуючи те, що в складі жирової суміші БЖЕ переважають жирні кислоти, 3 мононенасичених - олеїнова, а 3 поліненасичених - лінолева, важливим $\epsilon$ вивчення динаміки гідролітичних та окиснювальних змін ліпідів за температури зберігання $(2 \pm 2)^{\circ} \mathrm{C}$. Зміни ліпідів при зберіганні дослідних продуктів $\epsilon$ причиною появи в них сторонніх присмаків. Вільні жирні кислоти (ВЖК), що утворюються в результаті гідролізу ліпідів, підлягають окисненню, утворюючи пероксидні та карбонільні сполуки та каталізують розпад білкових речовин. Критичне значення місту ВЖК у системі характеризується збільшенням швидкості їх окиснення відносно швидкості накопичення. Цей період зберігання БЖЕ може бути охарактеризований як зона ризику, одночасно з'являється сторонній присмак і погіршення текстури БЖЕ.

3 метою запобігання накопичення вторинних продуктів окиснення ліпідів доцільно виявити «зону ризику» для розробленого складу БЖЕ. Динаміка гідролітичних та окиснювальних змін ліпідів дослідних і контрольних зразків БЖЕ при зберіганні наведена в табл. 3.

Аналіз результатів дослідження змін якості БЖЕ показав, що під час зберігання їх санітарно значимі мікробіологічні показники не перевищили допустимий рівень. Проте в процесі зберігання від 24 год до 32 год відмічалось погіршення текстури БЖЕ та накопичення небажаних речовин. Експериментально встановлено критичне значення концентрації вільних жирних

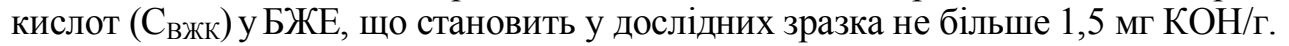

Вміст пероксидів на кінець досліду становить від 0,120 до 0,270 ммоль активного кисню. За величиною кислотного числа обгрунтовано граничний термін зберігання БЖЕ до двох діб [7].

Таблиия 3. Фізико-хімічні показники БЖЕ різних термінів зберігання за температури $2 \pm 2^{\circ} \mathrm{C}(n=3 ; P \geq 95)$

\begin{tabular}{|c|c|c|c|c|c|}
\hline \multirow{2}{*}{ Зразки } & \multicolumn{5}{|c|}{ Зберігання, год } \\
\cline { 2 - 6 } & 12 & 24 & 36 & 48 & 60 \\
\hline 1 & 2 & 3 & 4 & 5 & 6 \\
\hline \multicolumn{7}{|c|}{ Кислотне число, мг КОН } \\
\hline БЖЕ 1 (контроль) & 0,51 & 0,64 & 0,98 & 1,17 & 1,40 \\
\hline БЖЕ 2 & 0,54 & 0,73 & 1,02 & 1,26 & 1,46 \\
\hline БЖЕ 3 & 0,53 & 0,75 & 1,05 & 1,25 & 1,45 \\
\hline БЖЕ 4 & 0,54 & 0,74 & 1,04 & 1,26 & 1,48 \\
\hline БЖЕ 5 & 0,54 & 0,75 & 1,03 & 1,24 & 1,47 \\
\hline \multicolumn{7}{|c|}{ Пероксидне число, ммоль 1/2 О / кг } \\
\hline БЖЕ 1 (контроль) & 0,000 & 0,007 & 0,010 & 0,036 & 0,120 \\
\hline БЖЕ 2 & 0,000 & 0,007 & 0,011 & 0,040 & 0,129 \\
\hline БЖЕ 3 & 0,000 & 0,007 & 0,012 & 0,042 & 0,0130 \\
\hline БЖЕ 4 & 0,000 & 0,007 & 0,012 & 0,062 & 0,240 \\
\hline БЖЕ 5 & 0,000 & 0,009 & 0,012 & 0,086 & 0,270 \\
\hline
\end{tabular}




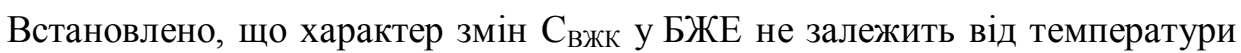
зберігання, а також від виду молочних білків, що вносяться. Проте зміна текстури БЖЕ здатна викликати руйнування коугуляційної структури емульciї, що може призвести до збільшення кількості вологи, яка може відокремитися під час теплового оброблення м'ясних виробів.

\section{Висновки}

1. Раціональне співвідношення індичого та свинячого жирів у складі БЖЕ становить 67:33. Так, співвідношення суми ненасичених і насичених кислот у ліпідах суміші свинячого й індичого жирів становить 66,42:28,99 проти рекомендованого 70:30.

2. Встановлено, що плазма крові Vepro 75 PSC - $1 \%$ та суміш молочних білків - $1 \%$ (казеїнат натрію - $70 \%$, маслянка - 30\%) завдяки емульгуючим властивостям запобігають втратам жиру у вільному стані при термічному обробленні й утворенню бульйонно-жирових напливів.

3. Тривалість зберігання БЖЕ при низьких плюсових температурах не повинна перевищувати двох діб.

\section{Література}

1. Иванов С.В. Исследование качественных показателей сырья мясоперерабатывающей отрасли Украины / С.В. Иванов, И.И. Кишенько, Ю.П. Крыжова // Maisto chemija ir technologija. Mokslo darbai (Food chemistry and technology. Proceedings) Kauno technologijos universiteto maisto institutas. — 2013. - T. 47. — \#. 1. - P. 35-42.

2. Семенова А.А. Влияние структурообразователей растительного происхождения на качество копчено-вареных продуктов из свинины / А.А. Семенова, Т.Г. Кузнецова, Е.К. Туниева // Мясная индустрия. — 2009. — № 1. - С. $34-38$.

3. Семенова А.А. К вопросу определения эффективных доз животного белка в рассолах для производства копчено-вареных продуктов из свинины / А.А. Семенова, Т.Г. Кузнецова, Е.К. Туниева // Все о мясе. — 2008. — № 5. - С. 28-31.

4. Семенова А.А. Исследование микроструктуры и качества копчено-вареных продуктов при введении различных доз высокомолекулярных структурообразователей / А.А. Семенова, Т.Г. Кузнецов, Е.К.Туниева // Материалы Всероссийской конференции. Углич, 2008. - С. 265-267.

5. Тартэ Р. Ингредиенты в производстве мясных изделий. Свойства, функциональность, применен / Р. Тартэ, ред.-сост. — Пер. с англ. — Санкт-Петербург : ИД Профессия, 2015. $-464 \mathrm{c}$.

6. Фейнер Г. Мясные продукты. Научные основы, технологии, практические рекомендации / Г. Фейнер; пер. с англ. Н.В. Магды. — Санкт-Петербург : Профессия, 2010. - 720 с.

7. ГОСТ 25292. «Жиры животные топленые пищевые». Технические условия, $1982 .-7$ с.

8. Кишенько I.I. Особливості використання білково-жирової емульсії в технології реструктурованих шинок / І.І. Кишенько, Ю.П. Крижова, В.О. Жук // Науковий вісник Львівського національного університету ветеринарної медицини та біотехнологій імені С.3. Гжицького. — 2017. — № 75, Том 19. — С. $97-101$. 